Gök, R., Kara, E. (2021). "Testing for Causality among CDS, Interest, and Exchange Rates: New Evidence from the Granger Coherence Analysis", Eskişehir Osmangazi Üniversitesi iïß Dergisi, 16(2), 427 - 445.

Doi: 10.17153/oguiibf.854172

Başvuru: 5.1.2021 Kabul: 22.4.2021

Araştırma Makalesi/Research Article

\title{
Testing for Causality among CDS, Interest, and Exchange Rates: New Evidence from the Granger Coherence Analysis ${ }^{1}$
}

Remzi Gök ${ }^{2}$

Erkan Kara $^{3}$

\begin{tabular}{|c|c|}
\hline $\begin{array}{l}\text { CDS, Faiz ve Döviz Kuru Arasındaki Nedensellik } \\
\text { ilişkisinin Analizi: Granger Coherence Metodundan Yeni } \\
\text { Kanıtlar }\end{array}$ & $\begin{array}{l}\text { Testing for Causality among CDS, Interest, and } \\
\text { Exchange Rates: New Evidence from the Granger } \\
\text { Coherence Analysis }\end{array}$ \\
\hline Öz & Abstract \\
\hline $\begin{array}{l}\text { Bu çalışmada } 2005 \text { ve } 2020 \text { dönemi kapsamında haftalık } \\
\text { ve aylık gözlemlerde CDS, faiz oranı ve USDTRY } \\
\text { arasındaki ilişki incelenmiştir. Test sonuçlarına göre tüm } \\
\text { değişkenler arasında pozitif yönlü bir ilişki bulunmuştur. } \\
\text { Granger Coherence test sonucuna göre değişkenler } \\
\text { arasında orta ve kısa döneme yoğunlaşan çift taraflı } \\
\text { nedensellik sonucuna ulaşılmıştır. } 37 \text { pencere } \\
\text { uzunluğundaki Boostraplı zamanla değişen nedensellik } \\
\text { test bulgularına göre, değişkenler arasında hem kriz hem } \\
\text { kriz dışı dönemlerde geçerli, ancak heterojen özellikler } \\
\text { gösteren nedensellik bulunmuştur. Ayrıca, COVID-19 } \\
\text { periyodunu içeren zaman aralığında, sadece faiz oranı ve } \\
\text { döviz kuru arasında geçerli tek yönlü nedensellik } \\
\text { bulgusuna rastlanmıştır. Bulgular hem yatırımcılar hem } \\
\text { de politika yapıcılar için önemli sonuçlar doğurmaktadır. }\end{array}$ & $\begin{array}{l}\text { We study the relationship between weekly and monthly } \\
\text { observations of CDS, interest, and exchange rates } \\
\text { (USDTRY) during 2005-2020 in Turkey. The findings } \\
\text { suggest a positive relationship between the variables. } \\
\text { The bivariate Granger Coherence approach indicates } \\
\text { that the dynamic causal and reverse causal interactions } \\
\text { mainly intensify in the short- and intermediate-term. } \\
\text { Using a bootstrap time-varying causality approach with a } \\
\text { fixed size of } 37 \text { weeks, the casual linkages are strong but } \\
\text { not homogenous in both non-crisis and crisis periods. } \\
\text { There is also a unidirectional causality running from } \\
\text { interest rates to foreign exchange rates during the } \\
\text { period of COVID-19, yielding important implications for } \\
\text { investors and policymakers. }\end{array}$ \\
\hline $\begin{array}{l}\text { Anahtar Kelimeler: CDS, Tahvil, COVID-19, Zamanla } \\
\text { Değişen Nedensellik, Granger Coherence }\end{array}$ & $\begin{array}{l}\text { Keywords: CDS, Bond, COVID-19, Rolling Causality, } \\
\text { Granger Coherence }\end{array}$ \\
\hline JEL Kodları: C53, D53, G12 & JEL Codes: C53, D53, G12 \\
\hline \multicolumn{2}{|c|}{$\begin{array}{l}\text { Araştırma ve } \\
\text { Yayın Etiği } \\
\text { Beyanı }\end{array}$} \\
\hline \multicolumn{2}{|c|}{$\begin{array}{l}\text { Çalışmanın tamamı iki yazar ile birlikte oluşturulmuştur. Bununla birlikte birinci (Introduction) ve ikinci (Literature } \\
\text { review) bölümleri Erkan Kara; diğer bölümler Remzi GÖK tarafından yapılmıştır. }\end{array}$} \\
\hline \multicolumn{2}{|l|}{ Katkıları } \\
\hline Yazarlar açısından ya da üçüncü taraflar açısında & çalışmadan kaynaklı çıkar çatışması bulunmamaktadır. \\
\hline
\end{tabular}

\footnotetext{
${ }^{1}$ It is the extended version of the summary paper presented online "IERFM'20 IV. International Economic Research and Financial Markets Congress" in Konya, Turkey.

${ }^{2}$ PhD, Dicle University, FEAS, Department of Business Administration, remzi.gok@dicle.edu.tr

${ }^{3}$ Assist. Prof., Necmettin Erbakan University, Faculty of Applied Sciences, Department of Accounting and Finance, ekara@erbakan.edu.tr
} 


\section{Introduction}

Credit Default Swaps (CDS) has gained significant attention in recent decades as it is considered to be an important risk measure indicator for sovereign countries. CDS indicators can be a good gauge for investors and policymakers for future decision-making. A rising or high level of CDS premium may produce a sign of an unpredictable territory for financial markets in which stock prices, exchange rates, and interest rates may fluctuate negatively. Or, in other words, a rising CDS premium for a market will increase economic shocks or risks. Because CDS spreads are recognized as a long-term financial risk indicator (Hammoudeh and Sari, 2011), and through the CDS market transmission, these instruments have a contagion effect on financial instruments, especially in the 2008 financial crisis (Apergis et al., 2019).

Before the CDS spreads has come to attention, economists tried to use financial indicators to see the risk level and future prediction of financial assets or economic indicators such as inflation, interest rates, and output level. For instance, while Bernanke (1990) used a yield curve and the economic activities to see their relation, Davis and Fagan (1997) used financial spreads to predict inflation and economic growth level. As the CDS spreads got popular recently as a risk indicator with relation to necessary macroeconomic variables, there have been many pieces of research that focused on the relationship mainly between CDS spread, government bonds, and exchange rates. For example, Forte and Pena (2009), and Foroni et al. (2018) are among others who studied the linkage between CDS spreads and exchange rate movements. Further, with the arrival of unprecedented infection of COVID-19, the world economies have come to a halt and risks have risen dramatically. Hence, CDS spreads increased at the start of the virus and these effects have been examined by Hofmann et al. (2020) and Feng et al. (2020).

There are several crucial factors behind the movement of the CDS premium. For example, exchange rate fluctuations are closely linked with default events in the case of currency devaluation (Augustin et al., 2019), and extreme currency movements are thought to be one of the main reasons behind sovereign credit risk movement (Foroni et al., 2018). The theory of the relation of the CDS-exchange rate is explained by Zhang et al. (2010). The authors argue that, by approaching from the perspective of the carry trade, since currencies are recognized as financial assets any perceived risk will result in a potential currency devaluation and this decline in value is due to worsening credit risks and a widening of credit default spreads. Because, in this case, the capital will start to leave the problematic country. The authors further argue that the shift in credit market conditions may be a good forecast gauge for some currencies. Similarly, there was found to be a good relationship between credit default swaps and interest rate, as stated by Hammoudeh and Sari (2011). The authors claim that while stock markets are leading financial indicators for the economy, government security markets, or bond markets are lagging and further state that CDSs are more liquid than government bonds and can quickly reflect market conditions. However, they also claim that CDSs and government bonds have relations, and CDS spreads can affect the interest rates of bond markets in the short and long run. Because, when negative shocks strike financial markets, the CDS spreads will increase, and as a result, investors consider long-term bonds as a safe heaven. As the demand for bonds and treasury-bill rises, the interest of these bonds and treasury-bills, therefore, will decrease. However, Wang et al., (2013) argue that for emerging economies the situation occurs opposite. The theory behind this is explained by Wang et al. (2013). The authors suggest that emerging countries' sovereign interest rate 
spread depends on several factors such as the level of public debts and predicted inflation rate. Hence, the interest rates on bonds reflect risk premium and as a result, a rising interest rate with risk perception will also increase the level of CDS spreads. Since Turkey is an emerging economy and its economic growth relies on new investment with capital from abroad, it has to borrow funds. In the case of any political or economic downturn, the economy looks vulnerable to credit risks. That is, interest rates start to raise together with CDS spreads, which causes capital flight out of the country and hence increases the risk perception against Turkey. Such risks end up with extreme currency volatility and cause Turkish Lira to lose value and visible decline in output level especially in the 2001 and 2008 crises. Even we can further argue that the same fear of capital flight occurred at the time of the COVID-19 pandemic for Turkey. Because once the effect of the pandemic has been felt by the world, stock markets plummeted and funds around the world were directed into safe havens such as US bond markets. Turkey experienced capital outflow and subsequently, interest rates start to increase together with CDS spreads to record levels. Not only exchange rates and interest rates are the main driver for CDS spreads, but some also argue that inflation, external debt, and trade openness can also influence CDS spreads (Aizenman et al., 2013). The authors suggest that the flexibility of government spending could be a good predictor of CDS spreads. However, at the time of the financial crisis, the prediction seems to be weak.

On the other hand, when looking at the theory of the relationship between interest rates and the exchange rate theory, Hacker et al. (2014) argue that interest rates and exchange rates are closely related. In the short run, the relation is negative (Andrieş et al., 2017; Şentürk and Dücan, 2014), while the linkage is identified to be positive in the long-run (Bautista, 2003; Sanchez, 2008). The theoretical background for exchange rate and interest rate differential (the difference between the interest rate of the home country and foreign country) is explained by Hacker et al. (2014). In the short run, the relation between the two variables is negative because the price levels do not change quickly. However, when the price level in the home country changes over time in the long run, the relationship between the exchange rate and interest rate turns out to be positive. The intuition behind this is that when the domestic interest rate increases, the capital inflows will happen into the domestic country, which in effect strengthens to value of the home currency relative to a foreign country in the short-run. This lies in the theory of the portfolio balance model of Branson's (1981) and Branson et al. (1979) works. In the long run, however, the perception is that domestic interest rates rise because of increasing inflation rates, which, in turn, cause domestic currency to devalue concerning foreign currencies. In the long run, the theory of Fisher (1930) hypothesizes that exchange rates and interest rates should be in equilibrium in the long term.

The objective of this paper is to contribute to the literature on CDS spreads by analyzing the relationship between CDS spreads, interest rate, and the exchange rate of Turkey in both crisis and non-crisis periods, such as the COVID-19 pandemic, by using unconditional correlations and employing a bivariate Granger coherence approach proposed by Lemmens et al. (2008) and rolling symmetric causality test of Hacker and Hatemi (2012). The analysis is built on the unit root and cointegration tests with two unknown structural breaks and it finds unidirectional and bidirectional causalities varying across frequency intervals regardless of data frequencies and intensifying in the intermediate-term and short-term between weekly 
observations, offering significant implications for investors and policymakers with heterogeneous expectations.

This paper is structured as follows. Section 2 provides a brief literature overview of the relationship between the pairs of CDS-USDTRY, CDS-BOND, and USDTRY-BOND. Section 3 describes the dataset and presents the theoretical framework of the methodology, Lemmens et al.'s (2008) Granger causality test. Section 4 discusses the empirical results and Section 5 offers concluding remarks and implications.

\section{Literature Review}

In the finance literature, there can be seen many research papers about the topic of CDS and its related financial and economic indicators in recent years. A growing number of papers can be found in the existing literature studying the linkage between CDS spreads and exchange rate movements (see e.g. Augustin et al., 2019; Forte and Pena, 2009; and Foroni et al., 2018). Of these empirical papers, Forte and Pena (2009) studied the relation between CDS and the stock market and bond spread while Aizenman et al. (2013) examined the linkage between CDS and inflation and external debt. Besides credit default spreads, for instance, Davis and Fagan (1997) used several financial indicators spreads to see their predictive power on future inflation economic growth of European countries. The analyzed spread was the yield curve (term structure of interest rate), the reverse yield gap between bond and equity yields, and the foreign bond yield differential. The authors found that these financial spreads give information about a possible change in inflation and output growth for the European countries. The yield curve was also used by Bernanke (1990), who uses several spreads of the yield of bonds and treasury bills of government and commercial papers to see their impact on economic activities such as inflation, industrial production, and employment level. Bernanke (1990) claims that the power of spread is more in the 1980s and weak afterward and believes that this is because of FED's actions of interest rates and substitutability among the other money market instruments due to deregulation and financial innovations.

Nonetheless, when it comes to literature for credit default swap and its relation with financial and economic indicators, many studies have come forth in recent years. Forte and Pena (2009) discuss the relationship between stock market credit spread, CDS spread, and bond spreads. Among the considered variables, stock prices are found to be more dominant over the CDS and bond market for North American and European companies and hence, favor CDS over bond markets in terms of being a leading indicator. Consistent with these empirical findings, Koy (2014) and Gün et al. (2016) suggested a one-way causal linkage from CDS spreads to interest rates in France, Italy, and Turkey; while Koy (2014) and Norden and Weber (2009) revealed a bidirectional causal relationship between CDS spreads and interest rates in Ireland, Spain, Portuguese, and Greece and in the US and EU countries. Similarly, Foroni et al. (2018) use daily CDS spreads with different maturities to predict future exchange rate movements for the short run time horizon by using a default risk model. The authors find a strong relationship between the CDS premium and the exchange rate in one day advance. Augustin et al. (2019) further contributed to the relationship between possible default events and currency devaluation. They employed CDS premium in Eurozone by using a no-arbitrage model. The authors suggest that when applying Quanto spreads for 17 Eurozone countries, credit risk and exchange rates seem to be moving together.

Another study that explored the relationship between CDS and the exchange rate movement is Kerstin and Helmut (2019), who studied the causal relationship between 
exchange rate and sovereign risk (CDS spread) for 16 emerging economies by using structural vector autoregressive models (SVARs). Their findings suggest that a fall in the value of currencies against the US Dollar will lead to an increase in CDS spread. They further point that a fall in the value of currency reduces the CS spread of countries that have private-sector currency exposures and so, they claim that currency depreciation, in turn, lowers the CDS spread for those countries. In contrast to this view, Zhang et al. (2010) suggest that increasing credit default spreads will lead to currency devaluation. In their research, using the VAR model, they found a significant leading from credit default swaps to foreign exchanges.

On the other hand, the relation between exchange rate and interest rate is analyzed by Hacker et al. (2014) through wavelet analysis to see the causality between the exchange rate and interest rates of seven countries. First, they used the impulse response function to find which variable is forcing others. In the short run, the relation was found to be negative, while the linkage was identified to be positive in the long-run. The authors further find that the causal relationship was time-dependent; namely, the relationship grows stronger as the time scale increases. For instance, MacDonald and Nagayasu (2000) investigated this relationship for a group of countries by using panel cointegration analysis. Their investigation period consists of floating exchange rate times. The study found that the interest rate and exchange rate have a long-run relationship. In addition to these findings, Drazen and Hubrich (2006) used the overnight interest rate to see its effect on the exchange rate for nine European countries. The authors found that when increasing overnight rates, the exchange rate positively benefits from this move in the short run. However, this relation may be negative and causes depreciation of the currency when the time horizon is over one year.

As for Turkey, a study by Kar et al. (2016) examined the relation between Credit Default Swap spread and the exchange rate of the Euro and Turkish Lira. By building an MS-VAR model with regime change and asymmetric frequency domain and rolling windows causality analysis, the authors found that CDS spreads are partially forcing variables for Euro and Lira. A similar econometric approach is used by Kayhan et al. (2013) to find the relation between the exchange rate and interest rate for Turkey. A non-linear and frequency domain causality test was employed to find the relation between BRIC countries and Turkey. Even though their results suggest a positive relationship between exchange rate and interest rate for China by stating interest rate shocks affect the exchange rate, there seems to be no effect at all for Turkey between these two variables. However, a positive correlation between the changes in CDS and exchange rates in Turkey is found by Akkaya (2017) during the 2008M01-2016M03 period.

Özpınar et al. (2018) highlighted the effect of the exchange rate and interest rate on the CDS premium for Turkey. When using the cointegration and Granger causality method, the authors found a long-run relation between US Dollar/Turkish Lira exchange rate and CDS premium. And the direction of influence is found to be from the exchange rate to CDS spreads. Besides, 2-year Turkish bond interest rates are also detected to be leading CDS spreads in Turkey.

Aksoylu and Görmüş (2018) used both symmetric and asymmetric causality tests to examine CDS-financial variables relationship for nine developing countries-Argentina, Brazil, Indonesia, Malaysia, Mexico, Philippines, Poland, Portugal, and Turkey-over the period of 2005 to 2015. The results showed that both positive and negative shocks from foreign exchange rates, the US interest rates, and VIX were significant factors in predicting CDS 
spreads in Argentina, Indonesia, Malaysia, and Portugal. Further, no evidence of symmetric and asymmetric causal linkage from financial variables to CDS spreads is found for the few countries, including Brazil, Mexico, the Philippines, and Turkey. Virtually similar findings were obtained by Çonkar and Vergili (2017), who investigated the CDS-exchange relationship through cointegration and causality tests during the 2010M01-2015M08 period in Turkey. On the other hand, Ozer and Kamisli (2016) found a unilateral short-run causality from interest rates to EURTRY and a reverse but long-run linkage in Turkey.

Gök (2020) studied, through the application of cointegration and causality tests as well as wavelet analysis, the relationship among interest rates, CDS spreads, Bist100 index, currency rates, and gold prices over the period January 2011-April 2019. The findings revealed evidence of significant cointegrating vectors in 13 out of 20 pairs of variables. The paper showed the bidirectional and unidirectional causal relationship between currency basket and CDS spreads and one-way causal linkage from interest rates to currency basket and CDS spreads to interest rates in the short-run. Additionally, the author found a significant causality-in-variance relationship running from interest rates to CDS and currency basket and from CDS spreads to the currency basket. The results of wavelet coherence analysis, however, highlighted that bond rates and currency basket were in phase, that is, they move in the same direction at the intermediate and longer frequency bands during the 2013-2019 period. Uzunoğlu et al. (2020), on the other hand, investigated the short- and long-term relationship between Turkey's 5-year CDS spreads, foreign exchange basket, and Foreign Politics Relations with Actors Index (DPA) during the period January 1, 2007, to March 30, 2020. They found a two-way causality between CDS and foreign exchange basket and demonstrated that there were no causation effects between the pairs of DPA \& foreign exchange basket and DPA \& CDS during the sample period. Furthermore, the findings of the GARCH model showed no significant impact from the DPA variable on the volatilities of CDS and foreign currency baskets in Turkey.

It could be better to mention findings revealed by researchers about the impact of COVID19 on related issues. Because, as stated before, this paper's latest data also covers the COVID19 period. For instance, Feng et al. (2020) suggest that the relation or spillovers between exchange rate and CDS spread have been bidirectional during COVID-19. However, before this pandemic, the authors also claim that the effect of the exchange rate on sovereign CDS spread was more forceful than the effect of CDS on the exchange rate. In their work, Hofmann et al. (2020) focused on emerging economies and analyzed their currency movement. The authors found that during the first phase of the disease, currencies faced sharp declines as a result of capital outflow. On the other hand, Kartal (2020) investigated the (global and macroeconomic) factors influencing the behavior of CDS spreads before and during the COVID-19 pandemic in Turkey. The findings of the MARS model reported a positive impact from COVID-19 pandemic cases on CDS spreads and from USDTRY, VIX, and some $\mathrm{MSCl}$ indices on CDS spreads in both periods.

\section{Data and Methodology}

\subsection{Data and Preliminary Analysis}

The data we consider for the relationship among CDS, interest, and exchange rates are the 5-year dollar-denominated CDS spreads, the 2-year government benchmark bond yields, and the USD to TRY exchange rate in Turkey, at weekly (815) and monthly (187) observations (weekly average prices) over the period 2005:04-2020:11. The purpose of using both weekly 
and monthly frequencies is to see whether the existence and degree of the relationship between variables vary according to the data frequency. The dataset is retrieved from the CBRT database and Bloomberg terminal. The starting point of the sample period was chosen to cover prior global financial crisis. Descriptive statistics for the continuously compounded returns, which is computed as 100 times the first difference of log prices, are summarized in Table 1.

Table 1: Descriptive Statistics

\begin{tabular}{|c|c|c|c|c|c|c|}
\hline & W_DL_BOND2 & W_DL_CDS5 & W_DL_USDTRY & M_DL_BOND2 & M_DL_CDS5 & M_DL_USDTRY \\
\hline Mean & -0.0292 & 0.0222 & 0.2162 & -0.1132 & 0.1545 & 0.95 \\
\hline Maximum & 16.9242 & 31.4294 & 17.9167 & 32.6142 & 59.7347 & 18.8063 \\
\hline Minimum & -29.2364 & -44.8311 & -7.3021 & -21.5384 & -28.6216 & -8.649 \\
\hline SD & 3.3112 & 6.6188 & 1.7274 & 7.9165 & 12.9204 & 3.6854 \\
\hline Skewness & -0.4567 & 0.2894 & 1.9077 & 0.4276 & 1.1816 & 1.2505 \\
\hline Kurtosis & 12.1254 & 7.6582 & 19.6623 & 4.8219 & 6.327 & 7.6501 \\
\hline$J B$ & $2852.64 * * *$ & $747.33 * * *$ & $9910.08^{* * *}$ & $31.39 * * *$ & $129.07 * * *$ & $216.06 * * *$ \\
\hline $\mathrm{N}$ & 814 & 814 & 814 & 186 & 186 & 186 \\
\hline
\end{tabular}

A perusal of Table 1 shows that the changes in weekly and monthly average prices of CDS and USDTRY exchange rates exhibit positive performance while the bond yields show a negative average return, indicating a poor performance for the Turkish bond market. Further, the changes in USDTRY have higher weekly and monthly returns than the other variables. Evidently, the changes in CDS yield the highest and lowest weekly and monthly observations during the sample period. Also, the value of standard deviation demonstrates that the changes in CDS have the highest weekly and monthly return volatility, followed in turn by the changes in interest and exchange rates. It shows that the distributions of the return series, except for the weekly bond changes, are positively skewed, i.e., they have a long right tail. Further, all variables exhibit excess kurtosis; namely, they are leptokurtic, pointing to the rejection of the hypothesis of normality, which is also confirmed by the JB test result at the $1 \%$ significance level.

We report the findings of the unconditional contemporaneous correlation test in Table 2. It includes two findings worth noting. First, all return series correlate significantly and positively with each other during the sample period. Second, the magnitude of the relationship is time-dependent, namely, as the frequency declines; the strength of the comovement gets stronger, that is, the estimated correlation coefficients, for example, between DL_USDTRY and DL_CDS5 are 0.650 and 0.695 for the weekly and monthly observations, respectively. In line with our findings, Akkaya (2017) and Özpınar et al. (2018) highlight a positive correlation between the changes in CDS and exchange rates in Turkey. Confirming the validity of the structural approach proposed by Merton (1974), our results reinforce the findings of Koy (2014), who reports a significantly positive relationship between the changes in CDS and interest rates in Portuguese, Ireland, Greece, Spain, Italy, Turkey, and France during the EU debt crisis. Further, the positive relationship for the pairs of DL_USDTRY \& DL_BOND reconciles the findings of Bautista (2003), who attributes the result to the 
ineffective interest rate defense of the currency in the Philippines during the two turmoil periods. Conversely, Andrieş et al. (2017), Hacker et al. (2014), and Sanchez (2008) reveal a significantly negative relationship in the short-run and positive association in the long-run, confirming the sticky-price models and the Fisher (1930) hypothesis and the purchasing power parity, respectively. Our results, however, contradict Şentürk and Dücan (2014), who find a significantly negative relationship between interest rates and foreign exchange rates in Turkey and conclude that the negative linkage causes Turkish investors holding foreign exchanges to shift their funds into financial assets with fixed returns when interest rates rise.

Table 2: Unconditional Correlation Estimations

\begin{tabular}{|c|c|c|c|}
\hline Variables & DL_CDS5 & DL_USDTRY & DL_BOND2 \\
\hline DL_CDS5 & & $0.695 * * *$ & $0.573^{* * *}$ \\
\hline DL_USDTRY & $0.650 * * *$ & & $0.529 * * *$ \\
\hline DL_BOND2 & $0.471 * * *$ & $0.446^{* * *}$ & \\
\hline
\end{tabular}

Note: $* * *$ signifies the rejection of the null hypothesis at the $1 \%$ significance level. The lower and upper triangular show the correlation results between the weekly and monthly observations, respectively.

Figure 1: Plots of Time Series
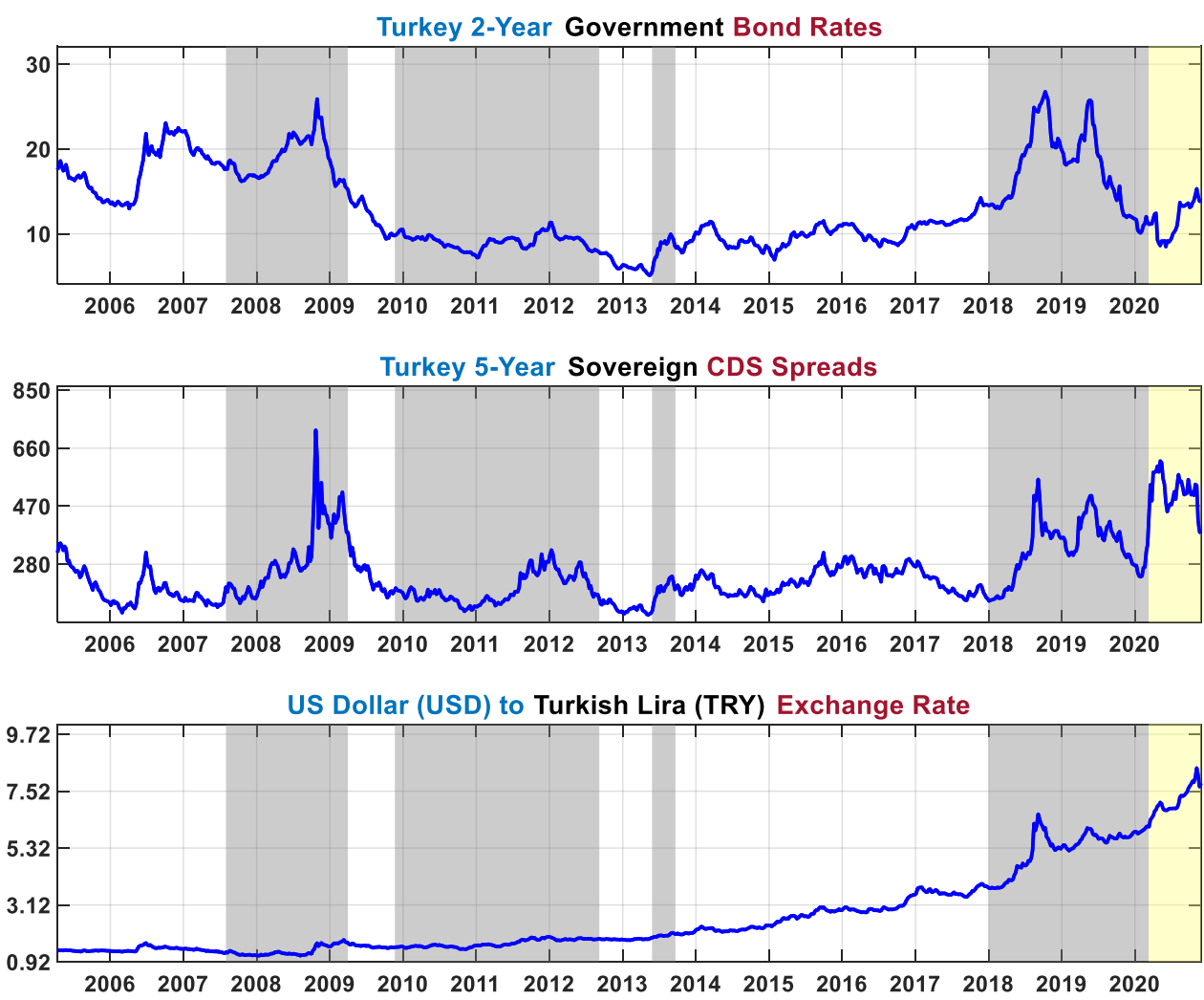

Note: The shaded areas represent crisis periods of 2007-2009 GFC, 2010-2012 EU Debt Crisis, 2013 Gezi Park Protests, 2018-2020 Turkey Currency Crisis, and COVID-19 Outbreak. 


\subsection{Methodology}

To investigate the relationship among our variables, we utilize Hatemi-J (2008) cointegration method with two unknown structural breaks and Lemmens et al. (2008) Granger coherence test. In the following section, only the technical details of the causality test will be given for the reason of brevity. For the other two well-known techniques, the readers are referred to the papers of Lee and Strazicich (2003) and Hatemi-J (2008) for a detailed technical overview.

In this paper, we prefer using the well-known frequency-domain causality test of Lemmens et al. (2008), which is based on the framework of Pierce (1979) to investigate the causal relationship. In their paper, Lemmens et al. (2008) remark that the traditional causality test explicitly ignores the possibility that the direction and/or strength of the causality relationship can vary over different frequencies. Following the idea of disentangling the causality relationship of Granger (1969), i.e., the spectral analysis, they (2008) argue that one can provide a richer and more comprehensive picture to heterogeneous agents with different holding periods in financial markets than traditional approaches with one-shot GC measure.

Before delving into the details, let us consider $X_{t}$ and $Y_{t}$ be two stationary time series of length $T$. To perform the Pierce (1979) approach, initially the univariate innovations series, $\varepsilon_{t}$ and $\epsilon_{t}$ are derived from the underlying two stationary series through ARMA filtering processes. Note that these two $\varepsilon_{t}$ and $\epsilon_{t}$ innovations series are white-noise processes with zero mean, and probably they are correlated with each other at different lags and leads.

Let us consider $\Upsilon_{\varepsilon}(\lambda)$ and $\Upsilon_{\epsilon}(\lambda)$ be the spectra of $\varepsilon_{t}$ and $\epsilon_{t}$ at frequency $\left.\lambda \in\right] 0, \pi$ [ which can be formulated as

$$
\Upsilon_{\varepsilon}(\lambda)=2 \pi^{-1}\left[\sum_{k=-\infty}^{\infty} \gamma_{\varepsilon}(k) \frac{1}{e^{i \lambda k}}\right] \& \Upsilon_{\epsilon}(\lambda)=2 \pi^{-1}\left[\sum_{k=-\infty}^{\infty} \gamma_{\epsilon}(k) \frac{1}{e^{i \lambda k}}\right]
$$

where $\gamma_{\varepsilon}$ and $\gamma_{\epsilon}$ represent the autocovariances of $\varepsilon_{t}$ and $\epsilon_{t}$ at lag $k$. The idea of the spectral representation is, as remarked by Lemmens et al. (2008), to decompose each data into a sum of uncorrelated components, each linked a particular frequency $\lambda$.

To study the relationship between $\varepsilon_{t}$ and $\epsilon_{t}$, we consider the cross-spectrum, $\Upsilon_{\varepsilon \epsilon}(\lambda)$, which allows us to determine this relationship as a function of frequency. With the representation of the co-spectrum and the quadrature, respectively, be as $C_{\varepsilon \epsilon}(\lambda)$ and $Q_{\varepsilon \epsilon}(\lambda)$, then, one could write this cross-spectrum as

$$
\Upsilon_{\varepsilon \epsilon}(\lambda)=C_{\varepsilon \epsilon}(\lambda)+i Q_{\varepsilon \epsilon}(\lambda)=2 \pi^{-1}\left[\sum_{k=-\infty}^{\infty} \gamma_{\varepsilon \epsilon}(k) \frac{1}{e^{i \lambda k}}\right]
$$

where $C_{\varepsilon \epsilon}(\lambda)$ and $Q_{\varepsilon \epsilon}(\lambda)$ denote the real and imaginary components. Further, $\gamma_{\varepsilon \epsilon}(k)=$ $\operatorname{Cov}\left(\varepsilon_{t}, \epsilon_{t-k}\right)$ signify the cross-covariance of $\varepsilon_{t}$ and $\epsilon_{t}$ at lag $k$. It is also possible to rewrite the equation in a non-parametrical way by

$$
\hat{\Upsilon}_{\varepsilon \epsilon}(\lambda)=2 \pi^{-1}\left[\sum_{k=-M}^{M} \hat{\gamma}_{\varepsilon \epsilon}(k) w_{k} \frac{1}{e^{i \lambda k}}\right]
$$


where $M, \gamma_{\varepsilon \epsilon}(k)$, and $w_{k}$ represent the maximum lag order, the empirical cross-covariances, and window weights with the condition of $k=-M, \ldots,+M$, respectively. With the condition of $1-|k| / M$, one can obtain the Barlett weighting scheme in the so-called weighted covariance estimator.

To measure the strength of the linear relationship in the frequency-domain, they (2008) offer using the coefficient of coherence, written as

$$
h_{\varepsilon \epsilon}(\lambda)=\frac{\left|Y_{\varepsilon \epsilon}(\lambda)\right|}{\sqrt{\Upsilon_{\varepsilon}(\lambda) Y_{\epsilon}(\lambda)}}
$$

Note that one cannot obtain any information about the direction of the relationship (if any) between two time series since the coefficient of coherence show the correlation coefficient in absolute value. The squared of coherence coefficient has an interpretation similar to the $R^{2}$ in a regression context.

With $0<\lambda<\pi$ and being appropriately rescaled conditions, the estimated squared coefficient of coherence at frequency $\lambda$ will converge to a $\chi_{2}^{2}$ under the null hypothesis that $h_{\varepsilon \epsilon}(\lambda)=0$

$$
2(n-1) \hat{h}_{\varepsilon \epsilon}^{2}(\lambda) \stackrel{d}{\rightarrow} \chi_{2}^{2}
$$

where $\stackrel{d}{\rightarrow}$ signifies convergence in distribution and $n$ equals to $T /\left(\sum_{k=-M}^{M} w_{k}^{2}\right)$. The null hypothesis $h_{\varepsilon \epsilon}(\lambda)=0$ versus the alternative hypothesis $h_{\varepsilon \epsilon}(\lambda)>0$ can be rejected if

$$
\hat{h}_{\varepsilon \epsilon}(\lambda)>\sqrt{\frac{\chi_{2,1-\alpha}^{2}}{2(n-1)}}
$$

where $\chi_{2,1-\alpha}^{2}$ denotes the $1-\alpha$ quantile of the chi-squared distribution with 2 d.o.f.

Following the framework of Pierce (1979), the cross-spectrum in equation (2) is decomposed into three components and rewritten as given

$$
\begin{aligned}
\Upsilon_{\varepsilon \epsilon}(\lambda)=\left[\Upsilon_{\varepsilon \Leftrightarrow \epsilon}+\right. & \left.\Upsilon_{\varepsilon \Rightarrow \epsilon}+\Upsilon_{\epsilon \Rightarrow \varepsilon}\right] \\
& =2 \pi^{-1}\left[\gamma_{\varepsilon \epsilon}(0)+\sum_{k=-\infty}^{-1} \gamma_{\varepsilon \epsilon}(k) \frac{1}{e^{i \lambda k}}+\sum_{k=1}^{\infty} \gamma_{\varepsilon \epsilon}(k) \frac{1}{e^{i \lambda k}}\right]
\end{aligned}
$$

where $Y_{\varepsilon \Leftrightarrow \epsilon}$ represents the instantaneous relationship between $\varepsilon_{t}$ and $\epsilon_{t} ; \Upsilon_{\epsilon \Rightarrow \varepsilon}$ and $\Upsilon_{\varepsilon \Rightarrow \epsilon}$ stand for the directional relationship between $\varepsilon_{t}$ and lagged values of $\epsilon_{t}$ and between $\epsilon_{t}$ and lagged values of $\varepsilon_{t}$, respectively.

The proposed spectral measure of GC is derived from the key property that $X_{t}$ does not Granger cause $Y_{t}$ when $\gamma_{\varepsilon \epsilon}(k)=0$ holds for all $k<0$. To investigate whether the lagged values of $X_{t}$ has predictive power on the current value of $Y_{t}$, one can use the second component of equation (7). Therefore, a natural estimator for the Granger coefficient of coherence at frequency $\lambda$ can be determined as 


$$
\hat{h}_{\varepsilon \Rightarrow \epsilon}(\lambda)=\frac{\left\|\hat{\Upsilon}_{\varepsilon \Rightarrow \epsilon}(\lambda)\right\|}{\sqrt{\hat{\Upsilon}_{\varepsilon}(\lambda) \hat{\Upsilon}_{\epsilon}(\lambda)}}
$$

with $\hat{Y}_{\varepsilon \Rightarrow \epsilon}(\lambda)$ as in equation (3), but with all weights $w_{k}=0$ for $k \geq 0$. After deriving the distribution of the estimator of the Granger coefficient of coherence from the distribution of the coefficient of coherence in equation (5), one can easily obtain the distribution of the squared estimated Granger coefficient of coherence at frequency $\lambda$, with $0<\lambda<\pi$ under the null hypothesis of $h_{\varepsilon \Rightarrow \epsilon}(\lambda)=0$ as

$$
2\left(n^{\prime}-1\right) \hat{h}_{\varepsilon \Rightarrow \epsilon}^{2}(\lambda) \stackrel{d}{\rightarrow} \chi_{2}^{2}
$$

with $n^{\prime}=T /\left(\sum_{k=-M}^{-1} w_{k}^{2}\right)$. Note that $w_{k}$ with negative indices are considered when computing $\hat{S}_{\varepsilon \Rightarrow \epsilon}(\lambda)$. The rejection of the null hypothesis, $h_{\varepsilon \Rightarrow \epsilon}(\lambda)=0$, of no GC at frequency $\lambda$ versus the alternative hypothesis $h_{\varepsilon \Rightarrow \epsilon}(\lambda)>0$ is true if the following condition holds

$$
\hat{h}_{\varepsilon \Rightarrow \epsilon}(\lambda)>\sqrt{\frac{\chi_{2,1-\alpha}^{2}}{2\left(n^{\prime}-1\right)}}
$$

\section{Empirical Results and Discussions}

Table 3 reveals the findings of the preliminary and necessary step before conducting cointegration and causality among our variables. For the unit root testing, we employ the minimum LM unit root test of Lee and Strazicich (2003) with two unknown structural breaks since our variables, as depicted in the figure above, exhibit jumps during global and local crisis periods such as 2007-2009 Financial Crisis, 2018-2020 Turkey Currency Crisis, and ongoing COVID-19 pandemic. The findings show that the unit root test fails to reject the null hypothesis for the log-level of Bond and USDTRY variables at the weekly and monthly frequencies when Model $A$ is chosen, but USDTRY seems to be trend-stationary at the $5 \%$ significance level with two breaks in the case of Model C. Conversely, it also reveals stationarity at the $1 \%$ level of significance around a broken trend and trend-stationary in the first log-difference of price series regardless of the frequency. Given the findings of the unit root test, we proceed to investigate a possible long-run association between the nonstationary variables in level, i.e., the pairs of W_BOND2-W_USDTRY, by employing the cointegration test with two unknown breaks proposed by Hatemi-J (2008) and report the results in Table 4. 
Table 3: Lee and Strazicich (2003) unit root test results

\begin{tabular}{|c|c|c|c|c|c|c|c|c|c|}
\hline Model & $\log (y)$ & LM & CV (10\%) & CV (5\%) & CV (1\%) & $\Lambda 1$ & $\Lambda 2$ & BP1 & BP2 \\
\hline \multirow{3}{*}{$\begin{array}{l}\frac{\varangle}{d} \\
\frac{0}{2} \\
\sum\end{array}$} & W_BOND2 & -2.127 & -3.504 & -3.842 & -4.545 & 0.52 & 0.53 & 426 & 429 \\
\hline & W_CDS5 & $-3.543^{*}$ & -3.504 & -3.842 & -4.545 & 0.23 & 0.85 & 187 & 696 \\
\hline & W_USDTRY & -1.995 & -3.504 & -3.842 & -4.545 & 0.85 & 0.86 & 696 & 698 \\
\hline \multirow{3}{*}{$\begin{array}{l}\frac{u}{\frac{v}{0}} \\
\frac{0}{2}\end{array}$} & W_BOND2 & -3.454 & -5.330 & -5.710 & -6.330 & 0.27 & 0.85 & 218 & 690 \\
\hline & W_CDS5 & -4.608 & -5.270 & -5.590 & -6.160 & 0.22 & 0.32 & 183 & 257 \\
\hline & W_USDTRY & -4.415 & -5.320 & -5.740 & -6.410 & 0.14 & 0.58 & 114 & 469 \\
\hline \multirow{3}{*}{$\begin{array}{l}\frac{\pi}{0} \\
\frac{1}{0} \\
\sum\end{array}$} & M_BOND2 & -2.597 & -3.504 & -3.842 & -4.545 & 0.24 & 0.87 & 44 & 163 \\
\hline & M_CDS5 & $-3.982 * *$ & -3.504 & -3.842 & -4.545 & 0.31 & 0.85 & 58 & 159 \\
\hline & M_USDTRY & -2.209 & -3.504 & -3.842 & -4.545 & 0.25 & 0.83 & 47 & 156 \\
\hline \multirow{3}{*}{$\begin{array}{l}\frac{\cup}{0} \\
\frac{0}{0} \\
\sum\end{array}$} & M_BOND2 & -4.04 & -5.320 & -5.740 & -6.410 & 0.25 & 0.54 & 46 & 101 \\
\hline & M_CDS5 & -4.632 & -5.270 & -5.590 & -6.160 & 0.19 & 0.28 & 36 & 53 \\
\hline & M_USDTRY & $-5.755^{* *}$ & -5.320 & -5.740 & -6.410 & 0.12 & 0.57 & 23 & 106 \\
\hline Model & $\Delta(\log (y))$ & LM & CV (10\%) & CV (5\%) & CV (1\%) & $\Lambda 1$ & $\Lambda 2$ & BP1 & BP2 \\
\hline \multirow{3}{*}{$\begin{array}{l}\varangle \\
\frac{\varangle}{0} \\
\frac{0}{\Sigma}\end{array}$} & W_BOND2 & $-19.668 * * *$ & -3.504 & -3.842 & -4.545 & 0.51 & 0.52 & 414 & 423 \\
\hline & W_CDS5 & $-20.755^{* * *}$ & -3.504 & -3.842 & -4.545 & 0.22 & 0.23 & 181 & 185 \\
\hline & W_USDTRY & $-23.275^{* * *}$ & -3.504 & -3.842 & -4.545 & 0.25 & 0.26 & 207 & 209 \\
\hline \multirow{3}{*}{$\frac{\frac{u}{d}}{\frac{0}{0}}$} & W_BOND2 & $-20.356 * * *$ & -5.310 & -5.670 & -6.450 & 0.52 & 0.59 & 423 & 481 \\
\hline & W_CDS5 & $-24.722 * * *$ & -5.320 & -5.730 & -6.320 & 0.85 & 0.86 & 695 & 703 \\
\hline & W_USDTRY & $-24.212^{* * *}$ & -5.320 & -5.730 & -6.320 & 0.85 & 0.87 & 694 & 712 \\
\hline \multirow{3}{*}{$\begin{array}{l}\frac{\varangle}{d} \\
\frac{0}{0} \\
\frac{0}{2}\end{array}$} & M_BOND2 & $-8.714^{* * *}$ & -3.504 & -3.842 & -4.545 & 0.22 & 0.57 & 41 & 106 \\
\hline & M_CDS5 & $-10.692 * * *$ & -3.504 & -3.842 & -4.545 & 0.24 & 0.25 & 44 & 46 \\
\hline & M_USDTRY & $-10.941 * * *$ & -3.504 & -3.842 & -4.545 & 0.82 & 0.84 & 153 & 157 \\
\hline \multirow{3}{*}{$\frac{\frac{u}{d}}{\frac{0}{0}}$} & M_BOND2 & $-9.76 * * *$ & -5.320 & -5.730 & -6.320 & 0.70 & 0.86 & 130 & 160 \\
\hline & M_CDS5 & $-11.191 * * *$ & -5.270 & -5.590 & -6.160 & 0.23 & 0.43 & 43 & 80 \\
\hline & M_USDTRY & $-11.26 * * *$ & -5.270 & -5.590 & -6.160 & 0.20 & 0.26 & 38 & 48 \\
\hline
\end{tabular}

Note: $* * *, * *$, or $*$ indicates the rejection of the null hypothesis with the presence of a unit root at $1 \%, 5 \%$, or $10 \%$ level of significance, respectively. W (M) represents weekly (monthly) average returns. $K 1(K 2)$ denotes the location of the first (second) break and it is used to determine the critical value. Similarly, the abbreviation BP1 (BP2) stands for the time location of the first (second) structural breakpoint. Further, Model A and Model C are a model with a break in intercept and a model with a break in intercept \& trend, respectively.

According to the test results provided in Table 4, Hatemi-J (2008) test fails to reject the null hypothesis of no cointegration despite taking into account two unknown structural breaks. In other words, there is no cointegration relationship between the weekly average prices of LN_USDTRY and LN_BOND, which do not move together in the long-run. 
Table 4: Hatemi-J (2008) Cointegration Test Results

\begin{tabular}{lll|lll|rrr}
\hline Independent & Dependent & ADF & TB1 & TB2 & Phillips Za & TB1 & TB2 \\
\hline W_LN_BOND2 & $\sim$ & W_LN_USDTRY & -5.179 & $2014-02-19$ & $2016-01-13$ & -44.959 & $2014-02-26$ & $2015-12-09$ \\
W_LN_USDTRY & $\sim$ & W_LN_BOND2 & -5.037 & $2009-12-02$ & $2015-11-04$ & -41.129 & $2009-05-20$ & $2015-12-09$ \\
\hline
\end{tabular}

Note: The abbreviation TB1 (TB2) stands for the first (second) structural breakpoint. Critical values for the ADF test are $-6.503,-6.015$, and -5.653 ; and for the Phillips Za test are $-90.794,-76.003$, and -52.232 at a $1 \%, 5 \%$, and $10 \%$ significance level, respectively.

Figure 2: Granger Coherence Analysis of Return Series
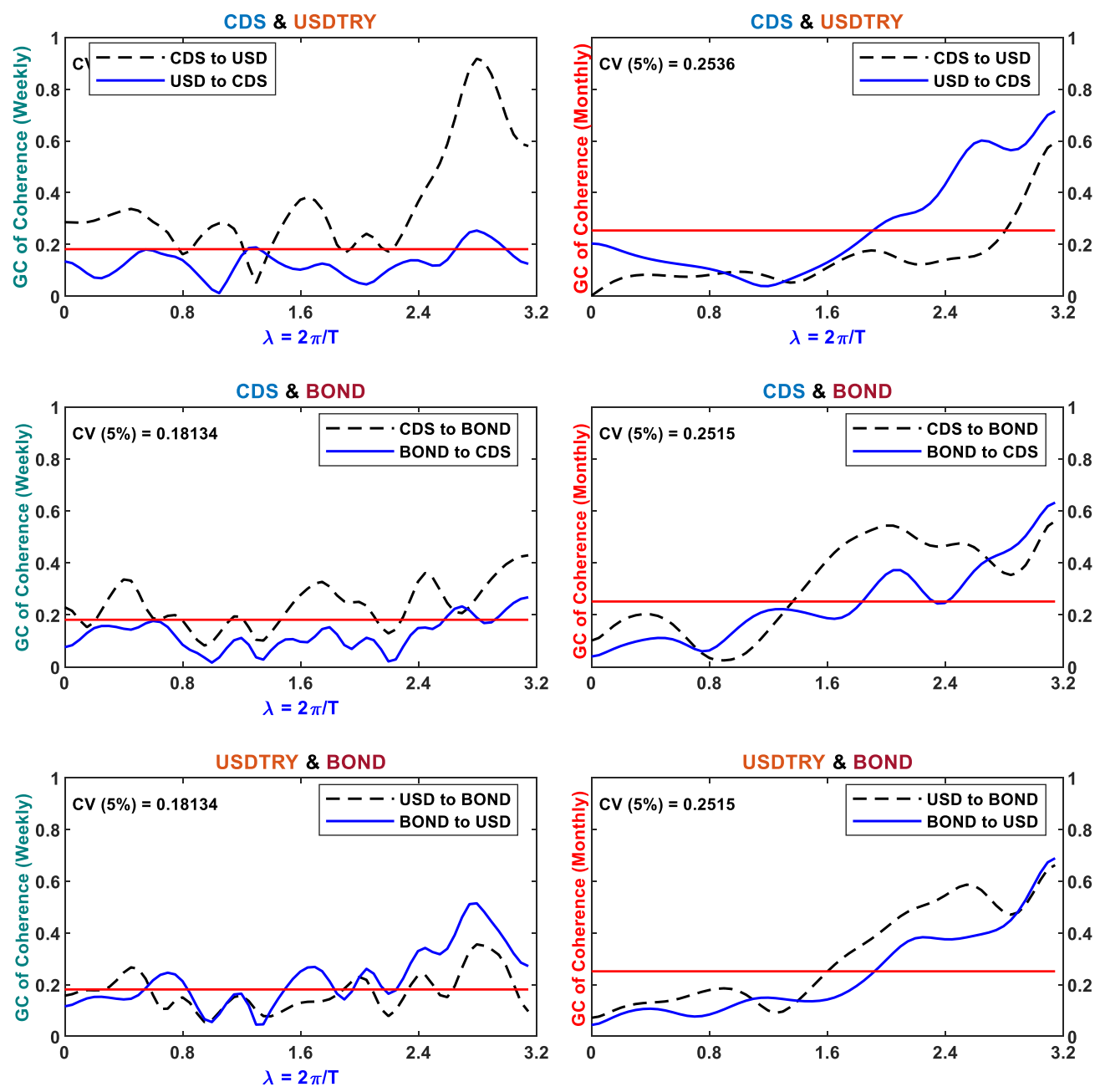

Note: The red solid line shows the critical value of a $5 \%$ significance level. The vertical and horizontal axis denotes Granger coefficients of coherence ranging between 0 and 1 and the frequency band $(\lambda)$ ranging between 0 and 3.2 with 63 points, respectively. Further, frequency points can be translated into a periodicity of $T$ weeks or months through the $T=2 \pi / \lambda$ equation.

Figure 2 depicts the findings of the frequency domain causality, i.e., Granger coherence, test proposed by Lemmens et al. (2008) in the left column and right column for weekly and 
monthly return series, respectively. Before proceeding further, it should be remarked that (i) all first-differenced series are filtered through ARMA models, (ii) the optimal lag length is determined by taking the square root of total observations, $M=\sqrt{T}$, (iii) the value of the coefficients of the Granger coherence test, on the vertical y-axis, ranges from 0 to 1 , whereas the frequency $(\lambda)$, on the horizontal $x$-axis, ranges from 0 to 3.14 , i.e., $\lambda \in[0, \pi]$. Besides, this test yields 63 frequency $(\lambda)$ points, which can also be translated into periodicity of $T$ weeks and months using the $2 \pi / \lambda$ equation. The causality relationship is tested with the $5 \%$ critical value ( 0.18 for weekly, 0.25 for monthly observations) for the null hypothesis, which is represented with a horizontal solid red-line. Finally, the left and right columns indicate the causality results for the weekly and monthly continuously compounded return series.

Looking at the first graph in Figure 2, it is evident that the changes in weekly CDS spread unidirectionally Granger-causes the changes in weekly USDTRY rate in nearly all frequency intervals. Namely, W_DL_CDS5 is significant in predicting $W_{-}$DL_USDTRY when $\lambda \in[0,0.75]$, $[0.90,1.2],[1.4,1.85],[1.94,2.14]$, and $[2.24,3.14]$ frequency bands, corresponding to the medium-run and short-run horizons. The reverse causal relationship that runs from W_DL_USDTRY to $W \_D L \_C D S 5$ seems visible in higher frequencies, $\lambda \in[1.25,1.30]$ and $[2.69,2.94]$, indicating the predictive power of USDTRY on CDS with the periodicity over 4.855.04 and 2.14-2.33 weeks. Conversely, there is significant evidence of causal linkages concentrated in the higher frequency bands, corresponding with cycles of 2.21 and 2 months for $\mathrm{CDS} 5 \Leftrightarrow$ USDTRY and with cycles of 2.25 and 3.23 months for CDS5 $\Leftarrow$ USDTRY at monthly observations. From these findings, we may conclude that the changes in CDS spread (USDTRY) could be used to predict the USDTRY (CDS) movements in the future and this is partially in line with the most recent studies including Akkaya (2017), Gün et al. (2016), and Zhang et al. (2010) with CDS $\Rightarrow F X$ and Aksoylu and Görmüş (2018), Çonkar and Vergili (2017), and Özpınar et al. (2018) with $F X \Rightarrow C D S$.

Turning our attention to the second graph in the left column, we see that W_DL_CDS5 Granger-causes W_DL_BOND2 in nearly all the frequency intervals including $\lambda \in[0,0.05]$, $[0.25,0.75],[1.15,1.2],[1.5,2.09]$, and $[2.29,3.14]$. The reverse causality, however, seems visible in the two higher frequency ranges $(2.59 \leq \lambda \leq 2.79)$ and $(2.94 \leq \lambda \leq 3.14)$, indicating the predictive power of CDS spreads on future movements in interest rates in the short-run. On the other hand, our findings show that M_DL_CDS5 unilaterally Granger-causes M_DL_BOND at the intermediate frequency bands of 1.4-1.8 and 2.34-2.39. Further, M_DL_CDS5 has reciprocal causal linkages with M_DL_BOND2 in Turkey at the intermediate and higher frequencies, $\lambda \in[1.85,2.29],[2.44,3.214]$, implying a feedback mechanism but temporary causality between the return series with a periodicity shorter than 3.41 months. Virtually similar results are obtained by Gün et al. (2016) who report CDS $\Rightarrow$ BOND relationship for Turkey; by Koy (2014) who finds CDS $\Rightarrow$ BOND association for France, Italy, and Turkey and reveals $\mathrm{CDS} \Leftrightarrow \mathrm{BOND}$ linkage for Ireland, Spain, Portuguese, and Greece; by Norden and Weber (2009) who report CDS $\Leftrightarrow$ BOND association at both daily and weekly frequencies in the US and EU. However, the findings contradict Koy (2014) with the CDS $\Leftrightarrow$ BOND relationship for Turkey.

An inspection of the third graph in the left column, on the other hand, reveals evidence of bidirectional causality between W_DL_BOND2 and W_DL_USDTRY at the higher frequency bands $(\lambda>2.29)$, shorter than 2.74 weeks. Further, W_DL_USDTRY Granger-causes W_DL_BOND2 at lower $(0.30 \leq \lambda \leq 0.55)$ and intermediate $(1.89 \leq \lambda \leq 2.04)$ frequency bands 
at the $5 \%$ significance level. The reverse causal relationship, however, holds at intermediate frequency ranges $(1.99 \leq \lambda \leq 2.14)$ and $(1.5 \leq \lambda \leq 1.8)$, and at lower frequency ranges $(0.55 \leq \lambda$ $\leq 0.80$ ). On the other hand, the results indicate one-way causality from M_DL_USDTRY towards M_DL_BOND2 for holding periods of 6.6-7.4 and 3.6-4.2 months, and bidirectional causality at the frequencies higher than $(\lambda \geq) 1.94$, that is, shorter than 3.23 months. These findings reinforce the conclusion drawn by Gün et al. (2016) and Şentürk and Dücan (2014) with $B O N D \Rightarrow U S D T R Y$ in Turkey; by Kayhan et al. (2013) with REER $\Rightarrow B O N D$ in the short-run in Brazil and India; with REER $\Rightarrow B O N D$ in the medium-run and $B O N D \Rightarrow R E E R$ in the long-run in China; by Ozer and Kamisli (2016) with BOND $\Rightarrow$ EURTRY in the short-run and with EURTRY $\Rightarrow$ BOND in the long-run in Turkey; by Hacker et al. (2014) who find bidirectional causality between the interest rate differential and Swedish Krona against USD, EUR, JPY, GBP, NOK, CHF, and KRW at the medium and higher wavelet scales; and by Özpınar et al. (2018) with USDTRY $\Leftrightarrow$ BOND in Turkey.

Figure 3: Rolling Symmetric Causality between Return Series
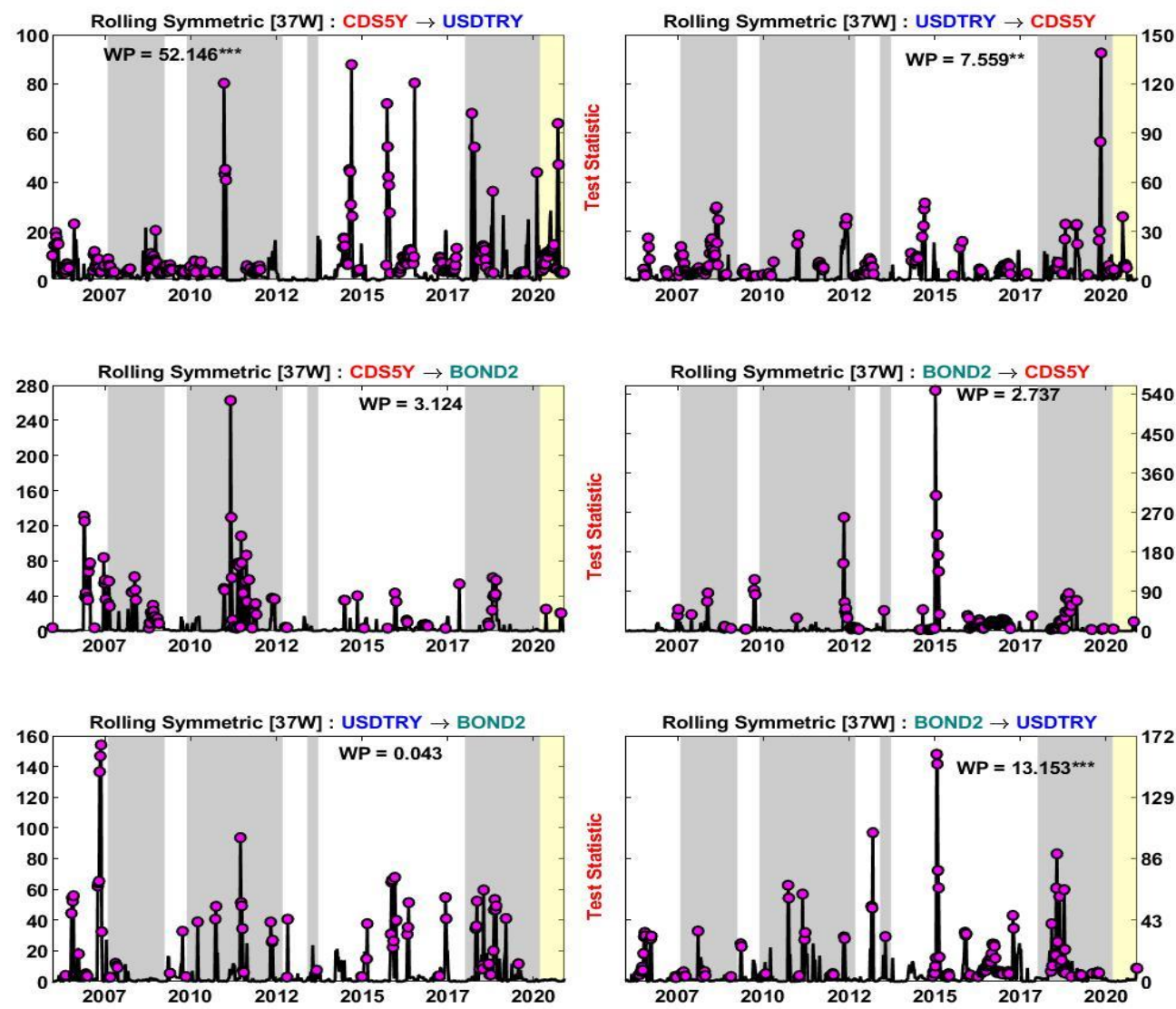

Note: The shaded areas represent crisis periods of 2007-2009 GFC, 2010-2012 EU Debt Crisis, 2013 Gezi Park Protests, 2018-2020 Turkey Currency Crisis, and COVID-19 Pandemic (yellow). A magenta-colored circle indicates the rejection of the null hypothesis of no causality relationship for a subsample of 37 weekly at a $10 \%$ significance level. The vertical axis shows the estimated Wald test statistics with a black solid line while the date on the horizontal axis, on the other hand, refers to the end of each sub-sample period. 
To test the null of non-causality among the variables during the periods of the global and local crisis and non-crisis periods, we incorporate the rolling regression technique to the symmetric causality test of Hacker and Hatemi (2012) and depict the findings in Figure 3. Note that, we use a moving sub-sample window of 37 weeks to fully cover the COVID-19 pandemic period from March to December 2020 in Turkey ${ }^{4}$. For each sub-sample period, we obtain Wald test statistics and a critical value of $10 \%$ significance level estimated from bootstrap simulations with 1000 replications between the log-level forms of the variables. If the estimated Wald test statistic exceeds the critical value, then it is marked with a magentacolored circle to denote that the null hypothesis of no causality is rejected at a $10 \%$ significance level. Besides, the optimal lag order of each rolling VAR model is determined using the Hatemi-J information criterion (2003).

Figure 3 illustrates the findings of sub-samples as well as the whole period (WP), located at the top of each plot. The results of the bootstrap full-sample Granger causality test show a bidirectional causality between $W_{-} D L_{-} C D S$ and W_DL_USDTRY, a unilateral causality [13.153***] running from W_DL_BOND2 to W_DL_USDTRY and no causality linkage between W_DL_CDS and W_DL_BOND2 during the whole sample period, confirming virtually the findings of Granger coherence test. The visual inspection of the rolling symmetric causality test, on other hand, shows that the magenta-colored circles, denoting an existence of causality, intensify considerably over both tranquil and turbulent periods. The causal impact from the CDS market on the Turkish currency market, for example, is significant for 239 out of 779 subsamples, and the reverse causality is significant at the $10 \%$ level for 181 out of 779 subsamples during the crisis and non-crisis periods. Similarly, the Wald statistics is 104 times higher than that of the $10 \%$ critical values for the testing of null of no-causality from the CDS spreads to the bond yields, while the null hypothesis is rejected 153 times for the reverse direction. The causality test also confirms that W_DL_USDTRY is 90 times Granger cause of W_DL_BOND2 with 145 times reverse causality for subsample periods.

The rejection rates of null hypothesis are, however, $37.5 \%$ [CDS $\Rightarrow$ USDTRY] and $61.4 \%$ [USDTRY $\Rightarrow C D S$ ] for the CDS-currency markets; $26.1 \%$ [CDS $\Rightarrow B O N D$ ] and $8 \%$ [BOND $\Rightarrow C D S$ ] for the CDS-bond markets; and 5.7\% [USD $\Rightarrow B O N D$ ] and 14.8\% [BOND $\Rightarrow U S D$ ] for the currencybond markets during the period of 2007-2010 global financial crisis. The rejection rate drops to $21.8 \%$ and $13.6 \%$ for the pair of CDS-currency markets; declines to $21.1 \%$ and increases to 9.5\% for the pair of CDS-bond markets; and rises to $8.8 \%$ and falls to $12.2 \%$ for the currencybond markets during the period of the European sovereign debt crisis (2010-2012). Besides, the findings reveal a unidirectional $[B O N D \Rightarrow C D S$ ] and bidirectional causality [USD $\Rightarrow B O N D$ ] during the Gezi Park protests (May-September in 2013) in Turkey, coinciding with the end of cheap money for emerging markets via the quantitative easing launched by the Fed. During the local currency crisis of 2018-2020, the highest rejection rate [32.5\%] among all cases is observed for [BOND $\Rightarrow C D S$ ] case with 37 times out of 114 subsamples. The null hypothesis that the CDS spreads do not have predictive power for the foreign exchange rate, however, is 21 times [18.4\%] whereas the null for the opposite direction is 22 times rejected. Finally, the paper reveals significant evidence for W_DL_CDS Granger-causing W_DL_USDTRY with a (maximum) $83.8 \%$ rejection rate of the null hypothesis during the COVID-19 pandemic period.

\footnotetext{
${ }^{4}$ In the selection of the rolling window length, the number of weeks between the date of the first COVID-19 case reported (March 11, 2020) in Turkey and the last week of the sampling period (November, 2020) was taken into account.
} 
During the whole period of the COVID-19 pandemic, i.e., the sample beginning in March 2020 and ending November 2020 with 37 observations, the null of non-causality is only once rejected for all cases, that is, the causality seems to be running from interest rates to foreign exchange rates with no reverse causality for the currency market and no significant results between the other markets. The findings of the whole period are in line with Gök (2020), who found a bidirectional causal relationship between currency basket and CDS spreads and oneway causal linkage from interest rates to currency basket and from CDS spreads to interest rates in Turkey. Moreover, the results partly reconcile the findings of Feng et al. (2020) who report a linear spillover effect in both directions between CDS and currency markets when accounting for the market fear variables during the COVID-19 period.

\section{Conclusion}

In this paper, we study the relationship among CDS, interest, and exchange rates (USDTRY) during 2005-2020 in Turkey using both weekly and monthly average observations. The findings of the cointegration test reveal evidence of no significant long-run linkage between the weekly observations of I(1) variables. In common with most existing papers, such as Bautista (2003), Koy (2014), Akkaya (2017), and Özpınar et al. (2018), unconditional correlations report a moderate and significant positive correlation between the return series, confirming the validity of the structural approach and the purchasing power parity theory. We also find one-way and two-way causalities that vary across frequency intervals regardless of data frequency. The rolling symmetric causality test with a fixed size of 37 weeks findings, however, show that there exist causal and reverse causal relationships intensifying in the intermediate and short-term between the underlying variables in both non-crisis and crisis periods and this is in line with Gök (2020) and partly reconcile the findings of Feng et al. (2020). Additionally, the null hypothesis of non-causality is rejected only for the bondcurrency markets with no reverse causality from the currency market during the whole period of the COVID-19 pandemic.

The findings have significant implications for investors and policymakers. The fact that the CDS market correlates positively with bond and currency markets could be seen as a leading indicator for rising risk in the last two markets, namely, a negative (positive) shock affecting the CDS market will be transmitted quickly and at varying magnitudes to these markets. For example, in the case of market turmoil in 2018, Turkey experienced a currency crisis in August. However, before this date, Turkish CDS spreads stayed high level indicating that risks are increasing in the economy. Only after increasing these risks, the central bank hiked the policy rate to prevent any further collapse of the Turkish Lira. Besides, the positive relationship indicates that these three instruments may be used as a diversifier by investors for risk management. The time-varying causalities between our variables provide valuable information for market agents with heterogeneous trading periods to monitor movements and predict future fluctuations in the aforementioned markets. From the policymaking perspective, the price movement in the CDS market may be conducive to predict the price fluctuations in bond and currency markets and vice versa in designing monetary policies to stabilize the volatilities in these markets and, therefore, to attain and sustain stability in Turkish financial markets. In conclusion, the examination of the relationship among our variables with including nonfinancial variables, such as social media posts, warrants future research. 


\section{Reference}

Aizenman, J.; Hutchison, M.; Jinjarak, Y. (2013), "What is the Risk of European Sovereign Debt Defaults? - Fiscal Space, CDS Spreads and Market Pricing of Risk", Journal of International Money and Finance, No. 34: 37-59.

Akkaya, M. (2017), "Türk Tahvillerinin CDS Primlerini Etkileyen Içsel Faktörlerin Analizi", Maliye ve Finans Yazıları, Vol. 1 No. 107: 130-145.

Aksoylu, E.; Görmüş, Ş. (2018), "Gelişmekte Olan Ülkelerde Ülke Riski Göstergesi Olarak Kredi Temerrüt Swaplari: Asimetrik Nedensellik Yöntemi", Ekonomik ve Sosyal Araştırmalar Dergisi, Vol. 14 No. 1: 15-33.

Andrieş, A. M.; Căpraru, B.; Ihnatov, I.; Tiwari, A. T. (2017), "The Relationship between Exchange Rates and Interest Rates in A Small Open Emerging Economy: The Case of Romania", Economic Modelling, No. 67: 261-274.

Apergis, N.; Christou, C.; Kynigakis, I. (2019), "Contagion across US and European Financial Markets: Evidence from the CDS Markets", Journal of International Money and Finance, No. 96: 1-12.

Augustin, P.; Chernov, M.; Song, D. (2019), "Sovereign Credit Risk and Exchange Rates: Evidence from CDS quanto Spreads", NBER, Working Paper, (2019.24506).

Bautista, C. C. (2003), "Interest Rate-Exchange Rate Dynamics in the Philippines: A DCC Analysis", Applied Economics Letters, Vol. 10 No. 2: 107-111.

Bernanke, B. (1990), "On the Predictive Power of Interest Rates and Interest Rate Spreads". New England Economic Review, (Nov), 51-68.

Branson, W. H. (1981), "Macroeconomic Determinants of Real exchange Rates", NBER, Working Paper, (1981.801).

Branson, W. H.; Halttunen, H.; Masson, Paul. (1979), "Exchange Rates in the Short Run: Some Further Results", European Economic Review, Vol. 12 No. 4: 395-402.

Çonkar, M. K.; Vergili, G. (2017), "Kredi Temerrüt Swapları Ile Döviz Kurları Arasındaki Illişki: Türkiye İçin Ampirik Bir Analiz", Ömer Halisdemir Üniversitesi iktisadi ve Idari Bilimler Fakültesi Dergisi, Vol. 10 No. 4: 59-66.

Davis, E. P.; Fagan, G. (1997), "Are Financial Spreads Useful Indicators of Future Inflation and Output Growth in EU Countries?", Journal of Applied Econometrics, Vol.12 No. 6: 701-714.

Drazen, A.; Hubrich, S. (2006), "A Simple Test of the Effect of Interest Rate Defence", Journal of the Japanese and International Economies, Vol. 20 No. 4: 612-636.

Feng, Q.; Sun, X, Liu, C.; Li, J. (2020), "Spillovers between Sovereign CDS and Exchange Rate Markets: The Role of Market Fear", The North American Journal of Economics and Finance, No. 101308.

Fisher, I. (1930), Theory of Interest: As Determined by Impatience to Spend Income and Opportunity to Invest It. Clifton: Augustusm Kelly Publishers.

Foroni, C.; Ravazzolo, F.; Sadaba, B. (2018), "Assessing the Predictive Ability of Sovereign Default Risk on Exchange Rate Returns", Journal of International Money and Finance, No. 81: 242-264.

Forte, S.; Pena, J. I. (2009), "Credit Spreads: An Empirical Analysis on the Informational Content of Stocks, Bonds, and CDS", Journal of Banking \& Finance, Vol. 33 No. 11: 2013-2025.

Gök, R. (2020), "Causality between Stock Market and Macroeconomic Variables in Turkey: New Evidence from Wavelet Coherence Analysis", Erciyes Üniversitesi iktisadi ve Idari Bilimler Fakültesi Dergisi, No. 56: 229-254.

Granger, C. W. (1969), "Investigating Causal Relations by Econometric Models and Cross-Spectral Methods", Econometrica: Journal of the Econometric Society, Vol. 37 No. 3: 424-438.

Gün, M.; Kutlu, M.; Karamustafa, O. (2016), "Gezi Parki Olaylarının Türkiye Kredi Temerrüt Swaplari (CDS) Üzerine Etkisi", Journal of Business Research Turk, Vol. 8 No. 1: 557-575.

Hacker, R. S.; Hatemi-J, A. (2012), "A Bootstrap Test for Causality with Endogenous Lag Length Choice: Theory and Application in Finance", Journal of Economic Studies, Vol. 39 No. 2: 144-160. 
Hacker, R. S.; Karlsson, H. K.; and Månsson, K. (2014), "An Investigation of the Causal Relations between Exchange Rates and Interest Rate Differentials Using Wavelets", International Review of Economics \& Finance, No. 29: 321-329.

Hammoudeh, S.; Sari, R. (2011), "Financial CDS, Stock Market and Interest Rates: Which Drives Which?", The North American Journal of Economics and Finance, Vol. 22 No. 3: 257-276.

Hatemi-J, A. (2003), "A New Method to Choose Optimal Lag Order in Stable and Unstable VAR Models", Applied Economics Letters, Vol. 10 No. 3: 135-137.

Hatemi-J, A. (2008), "Tests for Cointegration with Two Unknown Regime Shifts with an Application to Financial Market Integration", Empirical Economics, Vol. 35 No. 3: 497-505.

Hofmann, B.; Shim, I.; Shin, H. S. (2020), "Emerging market economy exchange rates and local currency bond markets amid the COVID-19 pandemic", Bank for International Settlements, (2020.5)

Kar, M.; Bayat, T.; Kayhan, S. (2016), "Impacts of Credit Default Swaps on Volatility of the Exchange Rate in Turkey: The Case of Euro", International Journal of Financial Studies, Vol. 4 No. 3: 1-18.

Kartal, M. T. (2020), "The Behavior of Sovereign Credit Default Swaps (CDS) spread: evidence from Turkey with the effect of COVID-19 pandemic", Available at SSRN 3642652.

Kayhan, S.; Bayat, T.; Uğur, A. (2013), "Interest Rates and Exchange Rate Relationship in BRIC-T Countries", Ege Academic Review, Vol. 13 No. 2: 227-236.

Kerstin, B.; Helmut, H. (2019), "Exchange Rates, Foreign Currency Exposure and Sovereign Risk”, DIW Discussion Papers, (2019.1792).

Koy, A. (2014), "Kredi Temerrüt Swapları ve Tahvil Primleri Üzerine Ampirik Bir Çalışma", International Review of Economics and Management, Vol. 2 No. 2: 63-79.

Lee, J.; Strazicich, M. C. (2003), "Minimum Lagrange Multiplier Unit Root Test with Two Structural Breaks", The Review of Economics and Statistics, Vol. 85 No. 4: 1082-1089.

Lemmens, A.; Croux, C.; Dekimpe, M. G. (2008), "Measuring and Testing Granger Causality Over the Spectrum: An Application to European Production Expectation Surveys", International Journal of Forecasting, Vol. 24 No. 3: 414-431.

MacDonald, R.; Nagayasu, J. (2000), "The Long-Run Relationship between Real Exchange Rates and Real Interest Rate Differentials: A Panel Study", IMF Econ Rev, No. 47: 116-128.

Merton, R. C. (1974), "On the Pricing of Corporate Debt: The Risk Structure of Interest Rates", The Journal of Finance, Vol. 29 No. 2: 449-470.

Norden, L.; Weber, M. (2009), "The Co-Movement of Credit Default Swap, Bond and Stock Markets: An Empirical Analysis. European Financial Management, Vol. 15 No. 3: 529-562.

Ozer, M.; Kamisli, M. (2016), "Frequency Domain Causality Analysis of Interactions between Financial Markets of Turkey", International Business Research, Vol. 9 No. 1: 176-186.

Özpınar, Ö.; Özman, H.; Doru, O. (2018), “Kredi Temerrüt Takası (CDS) ve Kur-Faiz İlişkisi: Türkiye Örneği", Bankacılık ve Sermaye Piyasası Araştırmaları Dergisi, Vol. 2 No. 4: 31-45.

Pierce, D. A. (1979), "R-Squared Measures for Time Series", Journal of the American Statistical Association, No. 74: 901-910.

Sanchez, M. (2008), "The Link between Interest Rates and Exchange Rates: Do Contractionary Depreciations Make a Difference?", International Economic Journal, Vol. 22 No. 1: 43-61.

Şentürk, M.; Dücan, E. (2014), "Türkiye'de Döviz Kuru-Faiz Oranı ve Borsa Getirisi İlişkisi: Ampirik Bir Analiz", Business \& Economics Research Journal, Vol. 5 No. 3: 67-80.

Uzunoğlu, S.; Ozdurak, C.; Dursun, S. (2020), “Dış Politik Aktörlerle Illişkiler, Döviz Kuru ve CDS Arasındaki İlişki: Türkiye Örneği 2007-2020", Maliye ve Finans Yazıları, No. 114: 129-128.

Wang, A. T.; Yang, S. Y.; Yang, N. T. (2013). "Information transmission between sovereign debt CDS and other financial factors: The case of Latin America", The North American Journal of Economics and Finance, No. 26, 586-601.

Zhang, G.; Yau, J.; Fung, H. G. (2010), “Do Credit Default Swaps Predict Currency Values?”, Applied Financial Economics, Vol. 20 No. 6: 439-458. 